\title{
PENGARUH PERPUTARAN PERSEDIAAN DAN PERPUTARAN PIUTANG TERHADAP LIKUIDITAS PADA PERUSAHAAN OTOMOTIF YANG TERDAFTAR DI BURSA EFEK INDONESIA PRIODE 2010-2013
}

\author{
QAHFI ROMULA SIREGAR \\ Fakultas Ekonomi Universitas Muhammadiyah Sumatera Utara \\ Jln. Kapten Mukhtar Basri No. 3 Medan 20238 \\ Telp.: 061 6619056, 6622400 Ext. 106 \& 108 Fax. 061 6625474-6631003 \\ e-mail : qahfiregarkhan@yahoo.com
}

\begin{abstract}
ABSTRAK
Penelitian ini bertujuan untuk mengetahui bagaimana pengaruh variable perputaran persediaan dan perputaran piutang terhadap likuiditas baik secara parsial maupun simultan pada perusahaan otomotif yang terdaftar di Bursa Efek Indonesia priode 2010-2013.

Populasi dalam penelitian ini adalah perusahaan otomotif yang terdaftar di Bursa Efek Indonesia priode 2010-2013 yang berjumlah 12 perusahaan. Sampel penelitian ini di tentukan dengan cara purposive sample. Jenis data yang di gunakan dalam penelitian ini adalah data skunder. Analisis data menggunkan analisis regresi berganda menggunakan SPSS 17.0.

Hasil penelitian ini menunjukkan bahwa variable perputaran persediaan secara parsial tidak berpengaruh signifikan terhadap likuiditas, perputaran piutang secara parsial berpengaruh signifikan terhadap likuiditas, dan perputaran persediaan dan perputaran piutang secara simultan berpengaruh secara signifikan terhadap Likuiditas.
\end{abstract}

Kata kunci : Perputaran Persediaan, Perputaran Piutang, Likuiditas

\section{PENDAHULUAN}

Perusahaan otomotif pada era globalisasi ini telah memberikan dampak positif pada perindustrian di bidang teknologi di Indonesia, telah banyak kita temukan perusahaan-perusahaan yang bergerak di bidang otomotif di negara kita, baik perusahaan yang bergerak dalam bidang industri maupun perdagangan. Yang di mana tujuan utama yang di harapkan perusahaan tersebut ialah mendapatkan laba atau nilai yang besar dengan target yang ingin di capai dengan memanfaatkan sumber daya yang ada secara efektif untuk kelangsungan hidup perusahaan. Kemajuan perusahaan dapat di lihat dari kelangsungan hidup perusahaan terutama di lihat dari tingkat likuiditasnya. Menurut Sugiono dan Untung (2008) Rasio ini bertujuan untuk menguji kecukupan dana, solvency perusahaan, kemampuan perusahaan membayar kewajiban-kewajiban yang harus di penuhi.

Rasio likuiditas ini digunakan untuk mengukur kemampuan perusahaan dalam menjamin kewajiban-kewajiban lancarnya. Perusahaan tidak memiliki standar minimum yang ditetapkan untuk rasio likuiditas, karna masing-masing perusahaan memiliki standar yang berbeda-beda.

Jadi dapat di simpulkan bahwa rasio likuiditas dapat dapakai untuk menilai kemampuan keuangan perusahaan dalam jangka pendek. Kemampuan perusahaan dapat 
di ukur dalam perbandingan antara aktiva lancar dengan hutang lancar. Dengan adanya modal atau aktiva lancar yang memenuhi target maka hutang lancar akan terealisasi dengan baik sehingga menjaga kelangsungan hidup perusahaan.

Pentingnya likuiditas yaitu karena perusahaan mampu atau tidaknya dalam memenuhi kewajiban jangka pendeknya. Apabila perusahaan dapat memenuhi kewajiban jangka pendeknya maka kelangsungan hidup perusahaan dapat berjalan dalam jangka pendek, begitu juga sebaliknya apabila perusahaan tidak mampu memenuhi kewajiban jangka pendeknya maka suatu perusahaan mengakibatkan kebangkrutan. Maka dengan itu, sangat penting bagi perusahaan dalam menjaga likuiditas suatu perusahaan itu sendiri.

Perusahaan otomotif pada umumnya memiliki aktivitas yang lebih berfluktuatif dibandingkan dengan perusahaan lainnya, karena perusahaan otomotif merupakan perusahaan yang menghasilkan barang siap pakai oleh konsumen atau masyarakat luas, sehingga dalam hal ini tingkat likuiditas perusahaan berperan penting dalam menjalankan aktifitas-aktifitasnya dengan efisien dan efektip. Perusahaan perlu melakukan analisa yang baik dalam hal likuiditas perusahaan dalam mengatur perputaran piutang dan perputaran persediaan sehingga berada dalam kondisi yang seimbang atau merata.

Jika dilihat dari 12 perusahaaan otomotif proyeksi pertumbuhan penjualan mengalami kenaikan yang relatif rendah, sehingga di tahun terakhir mengalami penurunan tetapi tidak begitu signifikan. Ini menunjukkan keseluruhan perusahaan mengalami penurunan penjualan. Penjualan seharusnya dapat menyumbangkan keuntungan yang besar kepada perusahaan, pada kenyataanya penjualan yang sering terjadi adalah penjualan secara kredit yang akan menimbulkan piutang usaha.

Penulis menggunakan perusahaan otomotif karena sebagian besar perusahaan melakukan kegiatan usahanya (penjualan) secara kredit. Penjualan kredit menimbulkan piutang dan terkait dengan ketersediaan persediaan sehingga dapat mengukur likuiditas perusahaan

\section{LANDASAN TEORI}

\section{Likuiditas}

Likuiditas merupakan salah satu faktor yang menentukan sukses atau gagalnya suatu perusahaan. Penyediaan kebutuhan uang tunai untuk memenuhi kewajiban jangka pendek menentukan sampai sejauh mana perushaan itu menanggung resiko. Atau dengan perkataan lain, kemampuan sautu perusahaan untuk mendapatkan kas atau kemampuanya merealisasikan aktiva non kas menjadi kas. Menurut Kasmir (2012) rasio Likuiditas merupakan rasio yang di gunakan untuk mengukur seberapa Likuidnya suatu perusahaan. Caranya adalah dengan membandinngkan komponen yang ada di neraca, yaitu total aktiva lancar dengan total passiva lancar (utang jangka pendek ).

Menurut Jumingan (2011) menyatakan bahwa likuiditas bertujuan menguji kecukupan dan, solvency perusahaan, kemampuan perusahaan membayar kewajiban yang segera harus di penuhi. Sedangkan menurut Menurut Kasmir (2012) Tujuan dan manfaat perusahaan rasio likuiditas adalah :

1) Untuk mengukur kemampuan perusahaan membayar kewajiban atau utang yang segera jatuh tempo pada saat di tagih

2) Untuk mengukur kemampuan perusahaan membayar kewajiban jangka pendek dengan aktiva lancar secara keseluruhan. 
3) Untuk mengukur kemampuan perusahaan membayar kewajiban jangka pendek tanpa mempperhitungkan persediaan atau piutang.

4) Untuk mengukur dan mambandingkan antara jumlah sediaan yang ada dengan modal kerja perusahaan

5) Untuk mengukur seberapa besar uang kas yang tersedia untuk membayar utang

6) Sebagai alat perencanaan ke depan, terutama yang berkaitan dengan perencanaan kas dan utang

7) Untuk melihat kondisi dan posisi likuiditas perusahaan dari waktu ke waktu dengan membandingkan untuk beberapa priode

\section{Perputaran Persediaan}

Persediaan merupakan salah satu aktiva lancar perusahaan yang sangat penting peranannya dalam operasional perusahaan. Menurut Kuswandi (2007) : "Persediaan merupakan berdasarkan dari unsur unsur persediaan barang dagangan (inventory), yaitu dapat berupa barang jadi (Inventory Of Finished Goods), barang dalam proses atau sering di sebut barang setengah jadi (Inventory of work in process), bahan baku (Inventory of direct Materials), Bahan pembantu (Inventory of indirect materials), dan persediaan barang-barang lain yang nilainya relatif kecil seperti alat tulis, keperluan administrasi, dan lain-alin (Inventory of supplies). Menurut Rudianto (2012) "Bahwa persediaan merupakan salah satu aset perusahaan yang sangat penting karena berpengaruh langsung terhadap kemampuan perusahaan untuk memperoleh pendapatan. Karena itu, persediaan harus di kelola dengan baik dan di catat dengan baik agar perusahaan dapat menjual produknya serta memperoleh pendapatan sehingga tujuan perusahaan tercapai."

Persediaan merupakan hal yang penting dalam menjada likuiditas perusahaan hal ini untuk mempertahankan eksistensi perusahaan denngan mencari laba atau keuntungan tertentu. Beberapa fungsi yang terkandung oleh persediaan dalam memenuhi kebutuhan perusahaan, Menurut Suryadi (2007) adalah sebagai berikut :

1) Menghilangkan resiko keterlambatan datangnya bahan-bahan yang di butuhkan untuk menunjang proses produksi perusahaan

2) Menghilangkan resiko penerimaan bahan baku yang di pesan tetapi tidak sesuai dengan pesanan sehingga harus di kembalikan

3) Menyimpan bahan/barang yang di hasilkan secara musiman (seasonal) sehingga dapat di gunakan seandainya pun bahan/ barang itu tidak tersedia di pasaran

4) Mempertahankan stabilitas operasi produksi perusahaan, berarti menjamin kelancaran proses produksi

5) Upaya penggunaan mesin yang optimal, karena terhindar dari terhentinya operasi produksi karena ketidak adaan persediaan

6) Memberikan pelayanan kepada langganan secara lebih baik. Barang cukup tersedia di pasaran, agar ada setiap waktu di perlukan. Khusus untuk barang yang di pesan (job order), barang dapat selesai pada waktunya sesuai dengan yang di janjikan (delivery date).

\section{Perputaran Piutang}

Piutang memiliki peranan yang sangat penting dalam aktivitas ekonomi dari satu perusahaan karena merupakan aktiva lancar perusahaan yang paling besar. Piutang timbul karena adanya penjualan barang atau jasa secara kredit. Penjualan secara kredit 
yang dilakukan oleh perusahaan secara otomatis akan mempengaruhi tingkat perputaran piutang.

Menurut Kasmir (2012) menyatakan bahwa "Piutang merupakan tagihan perusahaan kepada pihak lainnya yang memiliki jangka waktu tidak lebih dari satu tahun. Sedangkan menurut Rudianto (2012) "Piutang adalah klaim perusahaan atas uang, barang, atau jasa kepada pihak lain akibat transaksi di masa lalu. Menurut Hery (2009, hal.265) istilah piutang mengacu kepada sejumlah tagihan yang akan diterima oleh peerusahaan (umumnya dalam bentuk kas) dari pihak lain, baik sebagai akibat penyerahaan barang dan jasa secara kredit (untuk piutang pelangganyang terdiri dari atas piutang usaha dan dan memungkinkan piutang wesel).

Piutang mengacu pada sejumlah tagihan yang akan diterima oleh perusahaan (umumnya dalam bentuk kas) dari pihak lainya, baik sebagai akibat penyerahan barang dan jasa secara kredit (untuk piutang pelanggan yang terdiri atas piutang usaha dan kemungkinan piutang wesel), memberikan pinjaman (untuk piutang karyawan, piutang debitur yang biasanya langsung dalam bentuk piutang wesel, dan piutang bunga), maupun sebagai akibat kelebihan pembayaran kas kepada pihak lain (untuk piutang pajak).

Menurut Kasmir (2012) manfaat piutang adalah :

1. Perusahaan atau manajemen dapat mengetahui berapa lama piutang mampu di tagih selama satu priode. Kemudian manajemen juga dapat mengetahui berapa kali dana yang di tanam dalam piutang ini berputar dalam satu priode. Dengan demikian dapat di ketahui efektif atau tidaknya kegiatan perusahaan dalam bidang penagihan

2. Manajemen dapat mengetahui jumlah hari dalam rata-rata penagihan piutang (days of receivable) sehingga manajemen dapat pula mengetahui jumlah hari (berapa hari) piutang tersebut rata-rata tidak dapat di tagih

Dari manfaat pitang tersebut dapat di simpulkan bahwa piutang berguna sebagai dasar untuk penyusunan anggaran kas, karena penagihan piutang tersebut merupakan pemasukan kas. Serta sebagai alat pengawasan kerja yang membantu manajemen memimpin jalanya perusahaan.

\section{Kerangka Konseptual}

Inventory turnover ratio (ratio perputaran persediaan) merupakan satu rasio yang mengukur kemampuan perusahaan dalam mengelola persediaan, dimana semakintinggi inventory turnover (perputaran persediaan) yang diperoleh, semakin efisien perusahaan didalam melaksanakan operasinya. Current ratio (rasio lancar) merupakan rasio yang membandingkan antara aktiva lancar yang dimiliki perusahaan dengan hutang jangka pendek. Keterkaitan antara persediaan denagan tingkat likuiditas.

Penelitian yang dilakukan oleh Ezwita (2014) yang berjudul " pengaruh perputaran piutang, perputaran persediaan, return on asset dan rasio utang terhadap likuiditas pada perusahaan Industri dasar dan kimia listing di Bursa Efek Indonesia priode 2010-2013 adalah perputaran persediaan berpengaruh signifikan terhadap likuiditas

Penelitian yang dilakukan oleh Astuti dan Maelona (2012) menunjukkan bahwa hubungan perputaran piutang dengan likuiditas mempunyai hubungan yang kuat/erat dengan likuiditas, yang artinya ketika perputaran piutang meningkat maka likuiditas akan meningkat. Menurut Riyanto (2010), "Perusahaan selalu membutuhkan modal kerja untuk membelanjai operasinya sehari-hari, misalkan untuk memberikan persekot pembelian bahan mentah, membayar upah buruh, gaji pegawai dan lain sebgainya, 
dimana uang atau dana yang telah di keluarkan itu diharapkan akan dapat kembali lagi masuk dalam perusahaan dalam waktu yang pendek melalui hasil produksinya. Dengan demikian maka dana tersebut akan terus menerus berputar setiap priodenya selama hidupnya perusahaan." Penelitian yang di lakukan oleh Yezi Ezwita (2014) menunjukkan bahwa perputaran persediaan dan perputaran piutang berpengaruh secara signifikan terhadap likuiditas. Berikut ini merupakan gambar skema penelitian :

\section{Hipotesis}

Adapun hipotesis dalam penelitian ini adalah:

1. Ada pengaruh perputaran persediaan (inventory turnover ratio) terhadap likuiditas (current ratio).

2. Ada pengaruh perputaran piutang (account receivable turnover ratio) terhadap likuiditas (current ratio)

3. Ada pengaruh persedian (inventory turnover ratio) terhadap likuiditas (current ratio)

\section{METODE PENELITIAN}

Dalam penelitian ini, penulis melakukan penelitian dengan menggunakan pendekatan penelitian yaitu pendekatan asosiatif . Teknik pengumpulan data pada penelitian ini dilakukan dengan menggunakan teknik dokumentasi. Data yang digunakan dalam penelitian ini adalah data kuantitatif yang bersumber dari data sekunder. Adapun populasi dari penelitian ini adalah perusahaan yang bergerak dalam bidang otomotif yang terdaaftar di Bursa Efek Indonesia priode 2010-2014 yang berjumlah 12 perusahaan. Teknik penarikan sampel purposive sampling teknik melakukan sampel dengan pertimbangan tertentu. Jenis metode ini termasuk dalam metode penarikan sampel non probability sampling, yaitu metode pengambilan sampel yang tidak memberi peluang atau kesempatan yang sama pada setiap anggota populasi untuk dipilih menjadi sampel. Teknik analisis data yang digunakan dalam penelitian ini adalah analisis data kuantitatif seperti regresi berganda, uji t, uji $\mathrm{F}$ dan koefisien determinasi.

\section{HASIL DAN PEMBAHASAN}

\section{Uji Asumsi Klasik}

Uji asumsi klasik dilakukan bertujuan untuk memperoleh hasil analisis yang valid. Berikut ini pengujian untuk menentukan apakah kedua asumsi klasik tersebut di penuhi atau tidak.

\section{a. Uji Normalitas}

Pengujian ini untuk mengetahui apakah variabel independen dan variabel dependen atau keduanya berdistri normal atau tidak. Berikut ini dapat dilihat grafik hasil penelitian data yang telah diolah dengan pengujian SPSS versi 17,0 adalah sebagai berikut: 


\section{Gambar 1. Normalitas Histogram}



Pada gambar diatas diketahui bahwa grafik histogram menunjukkan pola berdistribusi normal. Karena kurva memiliki kecenderungan yang berimbang, baik pada sisi kiri maupun kanan dan kurva berbentuk menyerupai lonceng yang hampir sempurna.

\section{Gambar 2. Normalitas P-Plot of Regresi}

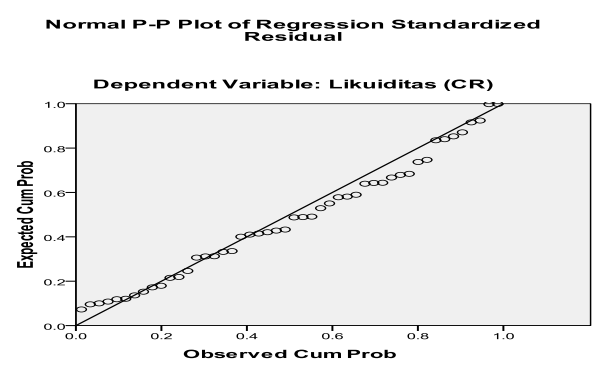

Pada grafik normal plot terlihat titik-titik menyebar disekitar garis diagonal. Dengan memperhatikan kedua grafik tersebut dapat dikatakan bahwa model regresi memenuhi asumsi normalitas, sehingga layak digunakan.

Salah satu uji statistik yang dapat digunakan untuk menguji normalitas residual adalah uji statistik. Kolmogrov Smirnov (K-S). Uji (K-S). Maka kriteria pengujian adalah sebagai berikut:

a) Jika angka signifikansi $>0,05$ maka data mempunyai distribusi normal

b) Jika angka signifikansi $<0,05$ maka data tidak mempunyai distribusi normal.

\section{b. Uji Multikolinieritas}

Ada tidaknya masalah multikolinearitas dalam regresi dapat dilihat dengan nilai VIF (Variance Inflactor Factor) dan nilai toleransi (tolerance). Uji multikolinearitas ini digunakan untuk menguji apakah regresi ditemukan adanya korelasi yang tinggi antara variabel bebasnya, karena model regresi yang baik seharusnya tidak terjadi korelasi diantara variabel independen tesebut, dalam hal ini ketentuannya adalah:

a) Jika VIF < 1,0, maka tidak terjadi mulitkolinearitas.

b) Jika VIF > 1,0, maka terjadi multikolineritas.

c) Jika Tolerance $>0.01$, maka tidak terjadi multikoleniaritas.

d) Jika Tolerance < 0.01, maka terjadi multikoleniaritas 
Tabel 1. Multikolinieritas

\begin{tabular}{|ll|r|r|}
\hline \multirow{2}{*}{ Model } & \multicolumn{2}{|c|}{$\begin{array}{c}\text { Collinearity } \\
\text { Statistics }\end{array}$} \\
\cline { 2 - 3 } & Tolerance & \multicolumn{1}{c|}{ VIF } \\
\hline $1 \quad$ (Constant) & & \\
Perputaran Persedian & .947 & 1.056 \\
Perputaran Piutang & .947 & 1.056 \\
\hline
\end{tabular}

a. Dependent Variable: Likuiditas (CR)

Berdasarkan tabel 1 uji multikolinearitas di atas nilai VIF dan tolerance menunjukkan bahwa semua variabel yang digunakan dalam penelitian ini nilai VIF lebih kecil dari 1,0 dan tolerance yang mendekati 1 atau besar dari 0.1 , yang berarti bahwa model regresi tidak terjadi multikolinearitas.

\section{c. Uji Heterokedastisitas}

Bertujuan untuk menguji apakah dalam model regresi terjadi ketidaknyamanan variance dari residual pengamatan 1 kepengamatan yang lain tetap. Hal seperti itu juga disebut sebagai homokedastisitas dan dan jika berbeda disebut heteroskedastisitas atau tidak terjadi heteroskedastisitas.

\section{Gambar Heterokedastisitas}



Berdasarkan gambar grafik scatterplot di atas terlihat bahwa titik-titik menyebar secara acak serta tersebar baik di atas maupun di bawah angka 0 pada sumbu Y. Hal ini disimpulkan bahwa tidak terjadi heterokedastisitas pada model regresi.

\section{Regresi Berganda}

Regresi berganda digunakan dalam penelitian ini bartujuan untuk mengetahui bagaimana variabel dependen dipengaruhi variabel independen bila variabel independen sebagai faktor prediktor. Berikut hasil pengolahan data dengan menggunakan SPSS versi 17.00 
Tabel 2. Pengujian Hipotesis Berganda

\begin{tabular}{|c|c|c|c|c|c|}
\hline \multirow[b]{2}{*}{ Model } & \multicolumn{2}{|c|}{$\begin{array}{l}\text { Unstandardized } \\
\text { Coefficients }\end{array}$} & \multirow{2}{*}{$\begin{array}{c}\text { Standardized } \\
\text { Coefficients } \\
\text { Beta } \\
\end{array}$} & \multirow[b]{2}{*}{$\mathrm{t}$} & \multirow[b]{2}{*}{ Sig. } \\
\hline & B & Std. Error & & & \\
\hline $1 \quad$ (Constant) & 244.776 & 26.949 & & 9.083 & .000 \\
\hline Perputaran Persedian & -5.485 & 3.743 & -.204 & -1.465 & .150 \\
\hline Perputaran Piutang & -7.325 & 3.142 & -.324 & -2.332 & .024 \\
\hline
\end{tabular}

a. Dependent Variable: Likuiditas

Dari tabel diatas maka di ketahui nilai-nilai sebagai berikut :

$$
\begin{array}{lll}
\text { Konstanta } & =244.776 \\
\text { Perputaran persediaan } & = & -5.485 \\
\text { Perputaran piutang } & = & -7.325
\end{array}
$$

Hasil tersebut di masukkan ke dalam persamaan regresi linier berganda sehingga di ketahui persamaan sebagai berikut :

$Y=244,776-5.485 X_{1}-7,325 X_{2}+e$

Keterangan :

1) Nilai "a" $=244,776$ menunjukan bahwa jika variable independen yaitu perputaran persediaan $\left(\mathrm{X}_{1}\right)$, perputaran piutang $\left(\mathrm{X}_{2}\right)$ dalam keadaan konstant atau tidak mengalami perubahan (sama dengan nol), maka likuiditas (Y) adalah sebesar $244,776$.

2) Nilai $X_{1}=-5.485$ menunjukan apabila kebijakan dividen mengalami kenaikan sebesar $100 \%$ maka akan mengakibatkan menurunnya kebijakan deviden perusahaan otomotif sebesar - 5.485 dengan asumsi bahwa perputaran persediaan tetap atau tidak berubah.

3) Nilai koefisien regresi $X_{2}=-7,325$ menunjukan apabila struktur aktiva mengalami kenaikan sebesar $100 \%$ maka akan mengakibatkan penurunan kebijakan hutang perusahaan otomotif sebesar - 7,325 dengan asumsi bahwa perputaran piutang tetap atau tidak berubah.

\section{Uji Parsial (uji t)}

Uji statistik t dilakukan untuk menguji apakah variabel bebas $(\mathrm{X})$ secara parsial

\begin{tabular}{|c|c|c|c|c|c|}
\hline \multirow[b]{2}{*}{ Model } & \multicolumn{2}{|c|}{$\begin{array}{c}\text { Unstandardized } \\
\text { Coefficients }\end{array}$} & \multirow{2}{*}{$\begin{array}{c}\begin{array}{c}\text { Standardized } \\
\text { Coefficients }\end{array} \\
\text { Beta }\end{array}$} & \multirow[b]{2}{*}{$\mathrm{t}$} & \multirow[b]{2}{*}{ Sig. } \\
\hline & B & Std. Error & & & \\
\hline $1 \quad$ (Constant) & 244.776 & 26.949 & & 9.083 & .000 \\
\hline Perputaran Persedian & -5.485 & 3.743 & -.204 & -1.465 & .150 \\
\hline Perputaran Piutang & -7.325 & 3.142 & -.324 & -2.332 & .024 \\
\hline
\end{tabular}
mempunyai hubungan yang signifikan atau tidak terhadap variabel terikat (Y)

Tabel 3. Hasil Uji t

Sumber : hasil SPSS 17.0 (2016)

Untuk kriteria Uji t dilakukan pada tingkat $\alpha=5 \%$ dengan dua arah $(0,025)$. Nilai $\mathrm{t}$ untuk $\mathrm{n}=48-2=46$ adalah 2.0129

\section{Pengaruh perputaran Persediaan Terhadap Likuiditas}


Berdasarkan hasil pengujian secara parsial pengaruh Perputaran Persediaan terhadap Likuiditas diperoleh $t_{\text {hitung }}$ sebesar $-1,465$ sementara $t_{\text {tabel }}$ sebesar 2,0129 dan mempunyai angka signifikan sebesar $0.150>0,05$. Berarti $\mathrm{H}_{\mathrm{a}}$ ditolak $\left(\mathrm{H}_{0}\right.$ diterima $)$, hal ini menunjukan bahwa tidak ada pengaruh yang signifikan antara pengaruh perputaran persediaan terhadap likuiditas pada perusahaan Otomotif yang terdaftar di BEI.

\section{Pengaruh Perputaran Piutang Terhadap Likuiditas}

Berdasarkan hasil pengujian secara parsial pengaruh perputaran piutang terhadap likuiditas diperoleh nilai $t_{\text {hitung }}$ sebesar $-2,332$ sementara $t_{\text {tabel }}-2,032$ dan mempunyai angka signifikan sebesar $0,024<0,05$. Berdasarkan kriteria pengambilan keputusan, dapat di simpulkan bahwa $\mathrm{H}_{0}$ ditolak $\left(\mathrm{H}_{\mathrm{a}}\right.$ diterima), hal ini menunjukan bahwa ada pengaruh yang signifikan antara perputaran piutang terhadap likuiditas pada perusahaan Otomotif yang terdaftar di BEI.

\section{Uji Simultan (Uji F)}

Uji $\mathrm{F}$ atau juga disebut juga dengan uji signifikansi serentak dimaksudkan untuk melihat kemampuan menyeluruh dari variabel bebas yaitu perputaran persediaan dan perputaran piutang untuk dapat menjelaskan tingkah laku atau keragaman likuiditas. Uji F juga dimaksudkan untuk mengetahui apakah semua variabel memiliki koefisien regresi sama dengan nol. Berikut adalah hasil statistik pegujiannya.

\section{Tabel 4. Hasil Uji F}

ANOVA $^{\mathrm{D}}$

\begin{tabular}{|ll|r|r|r|r|r|}
\hline Model & & Sum of Squares & Df & Mean Square & F & Sig. \\
\hline 1 & Regression & 57586.549 & 2 & 28793.275 & 4.833 & $.013^{\mathrm{a}}$ \\
& Residual & 268091.249 & 45 & 5957.583 & & \\
& Total & 325677.799 & 47 & & & \\
\end{tabular}

a. Predictors: (Constant), Perputaran Piutang, Perputaran Persedian

b. Dependent Variable: Likuiditas

Sumber : Hasil SPSS (2016)

Berdasarkan hasil uji $F_{\text {hitung }}$ pada tabel IV-10 di atas dapat nilai $F_{\text {hitung }} 4,833 \geq$ $F_{\text {table }} 3,28$ kemudian dilihat dengan hasil nilai probabilitas signifikan $0,013<0,05$, maka Ho ditolak dan (Ha diterima), sementara nilai $F_{\text {table }}$ berdasarkan $\mathrm{dk}=48-2-1=45$ dengan tingkat signifikan $5 \%$ adalah 3,20. Dari hasil perhitungan SPSS di atas menunjukkan adanya pengaruh secara signifikan perputaran persediaan dan perputaran piutang terhadap likuiditas pada perusahaan Otomotif yang terdaftar di Bursa Efek Indonesia.

\section{Koefisien Determinasi (R-Square)}

Koefisien Determinasi $\left(\mathrm{R}^{2}\right)$ berfungsi untuk melihat sejauh mana keseluruhan variabel independen dapat menjelaskan variabel dependen. Nilai koefisien determinasi adalah antara 0 dan 1 . Apabila angka koefisien determinasi semakin kuat, yang berarti variabel-variabel independen memberikan hampir semua informasi yang dibutuhkan untuk memprediksi variasi variabel dependen. Sedangkan nilai koefisien determinasi (adjusted $\mathrm{R}^{2}$ ) yang kecil berarti kemampuan variabel-variabel independen dalam menjelaskan variasi variabel dependen adalah terbatas. Berikut hasil pegujian statistiknya: 
Tabel 5. Koefisien Determinasi (R-Square)

Model Summary ${ }^{b}$

\begin{tabular}{|l|r|r|r|c|}
\hline Model & $\mathrm{R}$ & R Square & $\begin{array}{c}\text { Adjusted R } \\
\text { Square }\end{array}$ & $\begin{array}{c}\text { Std. Error of the } \\
\text { Estimate }\end{array}$ \\
\hline 1 & $.421^{\mathrm{a}}$ & .177 & .140 & 77.18538 \\
\hline
\end{tabular}

b. Dependent Variable: Likuiditas

Sumber : Hasil SPSS (2016)

Berdasarkan hasil uji koefisien determinasi pada tabel diatas, besarnya nilai adjusted $\mathrm{R}^{2}$ dalam model regresi diperoleh sebesar 0,177 . Hal ini berarti kontribusi yang diberikan Perputaran Persediaan dan Perputaran Piutang secara bersama-sama terhadap Likuiditas pada perusahaan Otomotif yang terdaftar di Bursa Efek Indonesia periode 2010-2013 adalah sebesar 0,177 sebesar 17,7\%, sedangkan sisanya 82,3\% dipengaruhi oleh faktor lain yang tidak termasuk dalam penelitian ini.

\section{PEMBAHASAN}

Pada pembahasan ini adalah akan dianalisis mengenai hasil temuan penelitian ini terhadap kesesuaian teori, pendapat, maupun penelitian terdahulu yang telah dikemukakan sebelumnya serta pola perilaku yang harus dilakukan untuk mengatasi hal tersebut. Berikut ini ada 3 bagian utama yang akan dibahas dalam analisis hasil temuan penelitian ini yaitu sebagai berikut:

\section{Hubungan Antara Perputaran PersediaanTerhadap Likuiditas}

Berdasarkan hasil penelitian di atas mengenai pengaruh antara Perputaran Persediaan terhadap Likuiditas pada Perusahaan Otomotif yang terdaftar di Bursa Efek Indonesia yang menyatakan bahwa $t_{\text {hitung }}>t_{\text {tabel }}$ yaitu $-1,465>2,0192$, dan $t_{\text {hitung }}$ berada di daerah penerimaan $\mathrm{H}_{0}$ sehingga $\mathrm{H}_{0}$ ditolak (Ha diterima), hal ini menyatakan bahwa tidak ada pengaruh antara perputaran persediaan terhadap Likuiditas pada Perusahaan Otomotif yang terdaftar di Bursa Efek Indonesia periode 2010-2013. Artinya peningkatan perputaran persediaan akan menurunkan penggunaan Likuiditas yang ada didalam suatu perusahaan.

Hasil penelitian ini menyatakan bahwa Perputaran persediaan berpengaruh dan negatif terhadap Likuiditas. Hal ini sejalan dengan Widharta (2012) yang mana perputaran persediaan tidak berpengaruh yang signifikan terhadap likuiditas. Tetapi berlawanan dengan penelitian yang dilakukan oleh Ezwita (2014) yang berkesimpulan bahwa perputaran persediaan berpengaruh signifikan dan terhadap Likuiditas.

\section{Hubungan Antara Perputaran Piutang terhadap Likuiditas}

Berdasarkan hasil temuan penelitian ini mengenai pengaruh antara perputaran piutang terhadap Likuiditas pada Perusahaan Otomotif yang terdaftar di Bursa Efek Indonesia yang menyatakan bahwa $t_{\text {hitung }} \quad t_{\text {tabel }}$ yaitu $-2,332 \quad 2,032$, dan $t_{\text {hitung }}$ berada di daerah penolakan $\mathrm{H}_{\mathrm{o}}$ sehingga $\mathrm{H}_{0}$ ditolak (Ha diterima), hal ini menyatakan bahwa perputaran piutang berpengaruh yang signifikan secara parsial terhadap likuiditas. Dengan menurunnya piutang tidak diikuti dengan menurunnya Likuiditas pada Perusahaan Otomotif yang terdaftar di Bursa Efek Indonesia periode 2010- 2013. 
Hasil penelitian yang menyatakan bahwa perputaran piutang tidak berpengaruh terhadap likuiditas. Hal ini tidak didukung atau tidak sejalan dengan penelitian yang dilakukan oleh Astuti dan Maelona (2012) yang menunjukkan bahwa Perputaran Piutang berpengaruh terhadap Kebijakan Likuiditas.

\section{Hubungan Antara Perputaran Persediaan dan Perputaran Piutang terhadap Likuiditas}

Mengenai pengaruh antara perputaran persediaan dan perputaran piutang terhadap likuiditas pada perusahaan Otomotif yang terdaftar di BEI pada penelitian ini sudah jelas terbukti tidak ada pengaruh secara simultan, dimana Berdasarkan

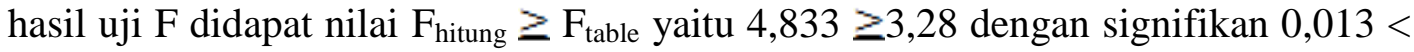
0,05 sementara nilai $\mathrm{F}_{\text {table }}$ berdasarkan $\mathrm{N}$ dengan tingkat signifikan $5 \%$ yaitu $\mathrm{dk}=$ n-k-1 maka 48-2-1 = 45 adalah 3,20. Karena $F_{\text {hitung }}$ lebih besar dari $\mathrm{F}_{\text {table }}$ maka Ho diterima (Ha ditolak), artinya ada pengaruh Perputaran Persediaan dan Perputaran Piutang secara simultan Terhadap Likuiditas pada perusahaan Otomotif yang terdaftar di Bursa Efek Indonesia. Maka dapat disimpulkan bahwa Berdasarkan hasil penelitian yang menyatakan bahwa peningkatan Perputaran Persediaan dan Perputaran Piutang dapat menutupi Likuiditas perusahaan. Hal ini didukung atau sejalan dengan penelitian yang dilakukan oleh Ezwita (2014 )yang berkesimpulan bahwa Perputaran piutang, perputaran persediaan, Return On Asset dan rasio utang berpengaruh signifikan terhadap likuiditas pada industri dasar kimia yang listing di BEI priode 2010-2013, berbeda dengan penelitian Widharta (2012) yang mana perputaran persediaan dan perputaran piutang tidak memiliki pengaruh signifikan terhadap likuiditas.

\section{KESIMPULAN}

Dari hasil analisis yang telah di bahas sebelumnya, maka di tarik kesimpulan sebagai berikut :

1. Perputaran persediaan tidak berpengaruh secara signifikan terhadap likuiditas pada perusahaan otomotif yang ada di Bursa Efek Indonesia

2. Perputaran piutang berpengaruh signifikan terhadap likuiditas pada perusahaan Otomotif yang ada di BEI

3. Perputaran persediaan dan perputaran piutang berpengaruh secara simultan terhadap likuiditas pada perusahaan otomoif yang ada di BEI

\section{DAFTAR PUSTAKA}

Arief Sugiono \& Edy Untung (2008), Panduan Praktis Dasar Analisa Laporan Keuangan ( Cetakan ke 2 ), Jakarta PT. Grasindo

Astuti dan Maelona (2012), Pengaruh modal kerja perputaran piutang terhadap Likuiditas (study kasus pada PT. Mayora Tbk yang terdaftar di bursa efek Indonesia Periode 2001-2012)

Bambang Riyanto (2008), Dasar-Dasar Pembelanjaan Perusahaan, Yogyakarta

Cetakan Kedelapan ), Penerbit : BPFE-Yogyakarta

Dermawan Sjahrial (2007), Pengantar Manajemen Keuangan ( Edisi 2 ) Jakarta Mitra Wacana Media.

Hery, (2012), Akuntansi Keuangan Menengah I ( Cetakan Kedua) Jakarta

PT Bumi Aksara 
Herliana, Kiagus Novriandy \& Triena Wahyuni (2009), Analisis Pengaruh Perputaran Persediaan Bahan Baku Terhadap Laba Perusahaan Pada PT Almi Caterindo Palembang

Jumingan. (2009), Analisis Laporan Keuangan (Cetakan Ketiga), Jakarta : PT Bumi Aksara

John J. Wild, K.R Subramanyam dan Robert F. Hasley (2005), Financial Stetement

Analiysis ( Cetakan ke delapan ) Jakarta : Salemba Empat

Kashmir (2012), Analisis Laporan Keuangan ( Cetakan Ke lima ) Jakata : PT. Raja

Grafindo Perkasa-Jakarta

Kuswandi, MBA (2008), Memahami Rasio-Rasio Keuangan Bagi Orang Awam (Cetakan ke 2), Jakarta : PT Gramedia

Lisa Puspita Sari (2013), Analisa Faktor Yang Mempengaruhi Likuiditas Pada Industri Ritel Yang Terdaftar Pada Bursa Efek Indonesia

Ribka Olivia Stephanie Widharta (2012) Analisa Pengaruh Perputaran Persediaan dan perputaran piutang terhadap likuditas perusahaan Industri Rokok yang terdaftar di Bursa Efek Indonesia

Rudianto (2012), Pengantar Akuntansi, Jakarta : Penerbit, (Erlangga), Jakarta

Suryadi Prawirosentono, (2007), Manajemen Operasi Analisis Dan Studi Kasus ( Edisi 4 ), Jakarta PT. Bumi Aksara

Sugiyono (2007), Metode Penelitian Bisnis Bandung Penerbit : Alfabeta

Supiandi (2012), Pengaruh Perubahan Anggaran Kas Terhadap Tingkat Likuiditas

Pada PT. PLN (Persero) Jawa Barat

Yesi Ezwita (2014), Pengaruh Perputaran Piutang, Perputaran persediaan, Return On Asset dan Rasio Utang Terhadap Likuiditas pada Perusahaan Industri Dasar dan Kimia yang Listing di Bursa Efek Indonesia Priode 2010-2013 